\title{
ORIGIN OF COBALT-SILVER ORES OF NORTHERN ONTARIO.
}

\begin{abstract}
Reginald E. Hore.
The rapidly increasing proved area of silver and cobalt bearing rocks of Northern Ontario has disclosed some new types of deposits, and has afforded additional information regarding the origin of the deposits and of the rocks containing them. It is the purpose of this article to present some results of study in field and laboratory.
\end{abstract}

\section{IN COLEMAN TOWNSHIP.}

The majority of shipping mines are located in the eastern half of this township, and are therefore within a few miles of the town of Cobalt. The producing veins occur in graywacke and feldspathic quartzites and conglomerates of Lower Huronian age, in metamorphosed, fine grained, green igneous rocks of Keewatin age, and in gray diabase-gabbro sills of Post Middle Huronian. In the Huronian sediments and in the diabase, the veins are nearly vertical, while in the Keewatin greenstones the inclination is irregular and the veins less well defined.

In his report ${ }^{1}$ on the camp, Dr. W. G. Miller suggested that the fissures now occupied by the cobalt-silver ores in the Lower Huronian were probably formed by the disturbance which accompanied the eruption of the diabase and gabbro, and that the ores may have been deposited from highly heated mineral laden waters associated with the eruption. In a second edition of this report he has suggested that the ores were possibly leached from the Keewatin greenstones, or from the Laurentian granites.

Dr. Van $\mathrm{Hise}^{2}$ also concludes that the diabase is the source of the ore, and believes that the Keewatin and the conglomerate are the main source of the calcite of the gangue minerals. $\mathrm{He}$

${ }^{1}$ W. G. Miller, Ann. Report, Bureau of Mines, Ontario, Vol. V., Ig05.

${ }^{2}$ C. R. Van Hise, Jour. of Canadian Mining Inst., Vol. X., 1907. 
suggests that the solutions bearing calcium carbonate were a factor in the precipitation of the metalliferous minerals.

A consideration of later discoveries seems, in large measure, to confirm the truth of these ideas.

\section{RECENT DISCOVERIES.}

Cobalt is now known to occur in several areas including the following, which are classed according to the country rock.

In Lower Huronian graywacke-

In Casey township, I 5 miles north of Cobalt. In diabase-gabbro-

In Pense and Ingram townships, 30 miles north of Cobalt.

In Whitson and adjoining townships, 25 miles west of Cobalt. In James and adjoining townships, I 5 miles north of Whitson. In the vicinities of Portage Bay, of Trout Lake, and west of Anima Nipissing Lake.

In Keewatin-

South of Lorrain township, I6 miles southeast of Cobalt.

Of these localities, Casey Twp., Whitson Twp., James Twp., and the area south of Lorrain show native silver in addition to cobalt minerals.

The following description applies to the rocks found over the large area including these deposits.

\section{DIABASE-GABBRO.}

The intimate connection of this rock with the ore deposits has been recognized by the prospectors for some time, and it is becoming more apparent as exploration advances.

It occurs in most cases in the form of large sills, a few hundred feet in thickness, lying nearly horizontal and parallel to the bedding of the Huronian sediments. The greater part of the sills is dark gray in color and holocrystalline. The chief minerals are augite and plagioclase (labradorite to bytownite), while ilmenite is generally present and quartz is common. At the edge of the sheets the rock is very fine grained, and, though markedly ophitic in texture, is not readily distinguished from intruded slates. A few feet from the edge the grain becomes quite noticeable, and 
at some distance very coarse textures were often found. These coarser portions, often pink in color, show a considerable percentage of quartz and orthoclase, often in micrographic intergrowth. Barlow's descriptions ${ }^{1}$ of numerous occurrences of this rock in the area covered by the Nipissing and Temiscaming map sheets, indicates that they are all derivatives of the same magma.

In petrographical character and in their relations to the Huronian sediments they are remarkably similar to diabase sills of the Lake Superior district, which are regarded as of Keweenawan (being the plutonic equivalent of the surface flows of the Copper district) or of Post-Keweenawan age. ${ }^{2}$

\section{VEINS IN DIABASE-GABBRO.}

Veins are not common in the diabase, and of these calcite are less numerous than quartz. Although quartz veins carrying cobalt ores are known, the silver is confined to veins having calcite gangue. In the rich deposits in Coleman Twp., there is little gangue, the veins being seldom more than a few inches in width and often composed entirely of ore. In some cases native silver is the most abundant filling, forming thin films along the joint planes.

The quartz veins frequently carry small amounts of pyrite and chalcopyrite. West of Wakemika Lake there are several quartz veins, one to two feet in width, which carry argentiferous galena along with pyrite, chalcopyrite, and a later filling of pale pink calcite.

Some barite veins in James Twp., are said to be argentiferous.

INTRUSIVES IN DIABASE-GABBRO.

There occur in the large sills small intrusions, some more, others less siliceous than the main mass.

In Coleman Twp., there are fine-grained dark-colored dikes of olivine diabase, while near Temagami there are small dikes of diabase porphyry.

More common and more interesting from an eonomic stand-

$\therefore$ A. E. Barlow, Geol. Sur. Canada, Ann. Rep., Vol. V., Part I., I897.

${ }^{2}$ A. C. Lane, Geol. Sur. Michigan, Vol. VI., Part I., pp. 219 et seq. A. E. Lawson, Geol. Sur. Minnesota, Bull. No. 8, p. 47, 1893 . 
point are the light-colored aplite veins. The width of most of these is to be measured in inches, and they are generally but a few hundred feet in length. They are fine grained and usually of pink color, being composed largely of quartz, orthoclase and the more sodic plagioclases. The proportions of quartz and feldspars vary considerably in the same vein. There is considerable chlorite in darker colored portions, and calcite fills in the interstices. Small crystals of apatite and titanite are inconspicuous but characteristic constituents.

Most of these aplite veins carry some pyrite, chalcopyrite, or galena, and some carry cobalt and silver ores. It was noted in some cases in James Twp., that the sulphides occur along fractures in the narrow veins and from this it is inferred that the metalliferous solutions followed the deposition of the aplite. It is also noted that the feldspars remain rather fresh, and that they were therefore inactive in precipitating the ore. The darkcolored silicate present however, is chlorite, and is probably the result of the action of these solutions on pyroxene or amphibole, yielding at the same time lime for the formation of calcite when carbon dioxide was available.

\section{DISSEMINATED ORE IN DIABASE-GABBRO.}

In the diabase which extends westwards from Anima Nipissing Lake to Lady Evelyn Lake, there are several showings of cobalt minerals, both in calcite veins and as disseminated crystals in the diabase. There is generally little or no surface indication of the latter; but on breaking the rock traces of cobalt bloom are found.

One such deposit, west of Diabase Lake, is associated with an aplite vein. This vein is about one foot in width and is exposed for about $\mathrm{I}_{50}$ feet, it carries some pyrite and chalcopyrite; but little cobalt. Parallel to the vein and for a few feet from its walls, the diabase contains disseminated crystals of smaltite which are more abundant along the joint planes. The chief unaltered constituent of the ore-bearing rock is feldspar. The crystals of smaltite, accompanied by some small titanite crystals, are embedded in calcite and chlorite, and more rarely in the feldspars. In the latter case it is to be noted that there are many cracks, partly 
filled with calcite, which have evidently served as channels for the introduction of the smaltite.

Another cobaltiferous specimen, also chloritic, from the same region shows some kernels of augite still undecomposed, and a high percentage of ilmenite.

Origin of Disseminated Ore.-The detection by the naked eye of scattered smaltite crystals in the diabase, suggests the possibility of its being an original constituent in the rock. On the other hand, the association with aplite suggests that the ore had its origin in the solutions that accompanied these intrusions.

The microscopic examination outlined above shows that the smaltite is of secondary origin. It was at first thought that possibly the augite was cobaltiferous; but, on examination, a specimen of the rock containing kernels of this mineral was found to contain no trace of cobalt.

Accordingly the following conclusions may be drawn: ( I) That the smaltite was introduced by solutions associated with the aplite intrusion; (2) that such solutions came after the crystallization of the aplite; (3) that the intrusion disturbed the diabase to such an extent that a zone was formed in the latter which was more permeable to the solutions that was the aplite itself ; (4) that these solutions had little action on the feldspars; but found other silicates quite active chemically. Further conclusions may be deduced from a consderation of the origin of the aplite.

Origin of the Aplite.-The most apparent difference between the aplite and the diabase is the color. This is due to a higher percentage of quartz and alkali-feldspars, and a corresponding lower percentage of dark-colored silicates, so that the aplite is generally light pink in color while the diabase is dark gray.

It has already been mentioned that portions of the diabase sill at some distance from their edge are coarse in texture and sometimes pink in color. Here again the difference in color is due to a greater development of quartz and less augite. The distance from the edge of the sheet, and the coarse texture show that these more siliceous portions have crystallized later than the main mass. This shows that differentiation has taken place in 
such a way that the melt has become more siliceous, possibly approaching a eutectic mixture. These pink coarse-textured portions have a mineralogical composition intermediate between that of the gray portion and that of the more siliceous aplite.

From the composition and the field relations it is thought therefore that the aplite is a later secretion from the further differentiated diabase magma.

The relation of the aplite to the diabase is very similar to that of "contemporaneous veins" in rocks described by Waller and Teall. ${ }^{\cdot}$ It is thought justifiable therefore to apply this term to the aplite occurrences.

Origin of the Metalliferous Solutions.-It has already been shown that the ores were deposited from solutions which followed the aplite intrusions.

The origin of these solutions cannot be proven; but the association with aplite suggests a genetic connection. It seems that as the diabase magma cooled and crystallized the melt was approaching a eutectic of predominating salic composition. If water and metallic sulphides and arsenides were being concentrated, this was probably by the formation of a solution whose constituents were not soluble in all proportions in the silicate solution. The former solution was not miscible with the latter, and remained liquid or gaseous after temperatures had been reached at which the latter had solidified. When fractures in the diabase provided means of escape, part of the metalliferous solution doubtless accompanied the aplite solution, and, as has been shown above, part escaped subsequent to the aplite deposition.

That such a deposit is due to extreme differentiation in the igneous magma, is in harmony with the expressed views of $\mathrm{J}$. E. Spurr ${ }^{2}$ regarding the origin of most metalliferous deposits.

While no silver was found in the rock sections examined, the occurrence of native silver with cobalt minerals in aplite in James and adjoining townships, indicates a similar origin for the silver.

${ }^{1}$ J. J. H. Teall, "British Petrography," London, I888, p. 275.

${ }^{2}$ J. E. Spurr, "A Theory of Ore Deposition," Econ. Geol., Vol. 2, pp. $78 \mathrm{I}-795$. 
While it has been shown that in the veins at Cobalt silver solidified later than cobalt minerals, ${ }^{1}$ the occurrence in aplite indicates that there was no great time interval.

Influence of Keewatin and Huronian Rocks.-Having concluded that the cobalt-silver-bearing solutions are the result of differentiation in the diabase magma, we have now to consider the role of the intruded rocks in precipitating the ore.

Van Hise has stated "that the calcite gangue could not be derived from the diabase since it contains no carbonates, or so small a quantity that it is negligible. But one of the most characteristic features of the Keewatin rocks is the presence of carbonates, among which calcite is the most abundant. Also the conglomerate, being composed of débris from the Keewatin, contains much carbonate." He infers "that the Keewatin and the conglomerate are the main source of the calcite of the gangue minerals," and suggests "that the precipitation of the ores was produced by the mingling of solutions, some of which came from the diabase bearing the ores, and others of which came from the conglomerate and Keewatin, bringing precipitating agents"; but "the mere cooling of the solution may have been a factor in the process."

In the discussion following Van Hise's paper, ${ }^{2}$ Miller pointed out concerning the cobalt-silver veins west of Peterson Lake, that "in practically all cases the silver values disappear in passing from the conglomerate to Keewatin but the smaltite and niccolite continue below the contact." He suggests "that during a period of secondary disturbance the silver filled in the cracks through the smaltite or older minerals." But the older Keewatin "seems to have escaped the effects of this slight disturbance, hence there were no cracks in it, and the solutions could not get through the Keewatin."

THE KEEWATIN.

A clearer idea of the part played by the intruded rocks is to be obtained by a study of the character of the Keewatin and Huronian formations over the wide area in which cobaltiferous diabase is now known to occur.

${ }^{1}$ Wm. Campbell and C. W. Knight, Econ. Geol.

"Jour. Canadian Mining Inst., Vol. X., I907. 
In Coleman township this formation is represented by igneous rocks only. Perhaps the most abundant type is a fine-grained green rock in which there is considerable chlorite and calcite, and still undecomposed remnants of augite. There are also intrusions of coarser-textured rocks which appear to be altered gabbros and diabases.

In Casey Twp. there is an outcrop of a dark green, fine-grained rock which appears to be an altered basalt, and in Tudhope township a coarse-textured greenstone intruded by Laurentian granite was observed.

In other areas sedimentary rocks are associated with those of igneous character. At Larder Lake there are auriferous cherty carbonates, while at Temagami there are carbonates and cherty iron ores.

A study of Miller's map ${ }^{1}$ shows that none of the ore-producing veins are located more than a few hundred feet away from igneous Keewatin rocks. Equally significant is the fact that in areas in which the latter are not found, the cobalt-silver deposits are less extensive, and many cobaltiferous veins contain no native silver.

As Van Hise has indicated, these rocks contain a considerable percentage of calcite which furnished the gangue. It is also to be noted that there are present many relatively unstable minerals, e. g., pyroxene, hornblende, and biotite, which are readily acted on by percolating waters. These minerals are active chemical agents, and doubtless by their reactions with ore-bearing solutions aided in the precipitation of the ores. From the field study it seems beyond doubt that such has been the case.

\section{THE LOWER HURONIAN.}

This formation is represented by graywacke slate, feldspathic quartzite or arkose, and graywacke conglomerate, in ascending order. The strata have, as a general rule, been but slightly disturbed from their original positions; but in some places are inclined as much as $45^{\circ}$. Their character has apparently been

${ }^{1}$ W. G. Miller and C. W. Knight, Map of Cobalt Area, Bureau of Mines, Ont., 1907. 
but little changed by igneous or dynamical agencies of metamorphism, except at the immediate border of the diabase where some hardening has taken place by a recrystallization of quartz.

In some areas, notably Temagami, Cobalt, Casey Twp., Wendigo Lake and Larder Lake, the graywacke slate and conglomerate predominate over the arkose. In others, notably the region from James Twp., to Lady Evelyn Lake, there is a greater thickness of the arkose.

From numerous petrographical descriptions by A. E. Barlow and G. H. Williams, in Barlow's report, supplemented by the writer's examination of the rocks in the more immediate vicinity of the ore deposits, the arkose is known to be made up almost entirely of quartz, orthoclase, plagioclase, sericite and chlorite. Quartz and orthoclase predominate, and of the plagioclases the more sodic varieties are most abundant. The grains are often subangular and much fractured, their size is that of a medium grained granite.

The graywacke, so far as can be determined, is made up of similar minerals more finely pulverized. The percentage of chlorite is higher; but there is an absence of fragments of primary ferro-magnesian minerals, and the rock is therefore not a: typical graywacke.

The pebbles in the conglomerate represent numerous types of Keewatin and Laurentian igneous rocks, and occasional cherty sediments. Light colored granites, probably Laurentian, are the most abundant of the pebbles.

From the character and composition of the mineral fragments which constitute them, there can be little doubt that the arkoses were formed from the granitoid Laurentian rocks, and not from the metamorphosed greenstones of the Keewatin. It follows also that much of the graywacke is the finer material from the same source; but what percentage of the graywacke is made up of detritus of the Keewatin cannot be determined.

Dr. A. P. Coleman ${ }^{1}$ has shown that some pebbles in the conglomerate at Cobalt have suffered from glacial action. From the examination of numerous basal unconformities however,

${ }^{1}$ A. P. Coleman, Jour. Geol. 
one must conclude that they are not due to morainal deposition following the grinding action of glaciers. A photograph of one of these unconformities is shown in Miller's report.

The gradual transition from slate and arkose to the upper conglomerate bed shows that the latter is not of the common glacial type. The boulders of the upper bed, however, may be the erratic deposits of drifting ice; though glacial material is apparently a minor factor if present at all.

Bell ${ }^{1}$ describes the conglomerate as a volcanic breccia. Miller suggests that "some of the delicately banded graywacke slate may represent volcanic dust or fine grained pyroclastic material," but that the lower conglomerate is not pyroclastic and is made up of fragments of the adjacent older series.

The examination of thin sections of graywacke shows an absence of glass or mineral fragments so characteristic of volcanic dust. The chemical analysis shows it to be of a composition similar to an ordinary palaeozoic shale.

\begin{tabular}{|c|c|c|c|c|c|c|c|c|c|}
\hline A & $\begin{array}{c}\mathrm{SiO}_{2} \\
60.15\end{array}$ & $\begin{array}{l}\mathrm{Al}_{2} \mathrm{O}_{3} \\
\mathrm{I} 6.45\end{array}$ & $\begin{array}{c}\mathrm{Fe}_{2} \mathrm{O}_{3} \\
4.04\end{array}$ & $\begin{array}{l}\mathrm{TiO} \\
.76\end{array}$ & $\begin{array}{c}\mathrm{F} \\
2 .\end{array}$ & & $\begin{array}{l}\mathrm{CaO} \\
\mathrm{I} .4 \mathrm{I}\end{array}$ & $\begin{array}{l}\mathrm{MgO} \\
2.32\end{array}$ & $\begin{array}{c}\mathrm{Na}_{2} \mathrm{C} \\
\mathrm{I} . \mathrm{OI}\end{array}$ \\
\hline & 62.74 & I6.94 & 5.07 & & I. & & I. 39 & 3.05 & 6.07 \\
\hline & $\begin{array}{l}\mathrm{K}_{2} \mathrm{O} \\
3.60\end{array}$ & $\begin{array}{l}\mathrm{H}_{\overline{2}} \mathrm{O} \\
4.7 \mathrm{I}\end{array}$ & $\begin{array}{l}\mathrm{CO}_{2} \\
\mathrm{I} .46\end{array}$ & $\begin{array}{l}\mathrm{SO}_{3} \\
.58\end{array}$ & $\begin{array}{c}\mathrm{C} \\
88 .\end{array}$ & $\begin{array}{l}\mathrm{BaO} \\
.04\end{array}$ & $\begin{array}{r}P_{2} \\
. I\end{array}$ & & \\
\hline & & 3.56 & & & & & & & \\
\hline
\end{tabular}

(A) is a composite analysis of $5 \mathrm{I}$ palaeozoic shales, by $\mathrm{H}$. N. Stokes of the U. S. G. S.

(B) is the analysis of graywacke slate from the Little Silver Mine, made by A. G. Burrows of the Ontario Bureau of Mines.

The writer concludes therefore, (I) that there was no volcanic activity contemporaneous with the Lower Huronian, (2) that these rocks were formed entirely of the detritus of the Laurentian and Keewatin formations, (3) that the Arkoses, at least, are primarily of Laurentian origin

INFLUENCE OF LOWER HURONIAN ROCKS.

Attention has already been drawn to the fact that the feldspars were but slightly, if at all, altered by the ore-bearing

${ }^{1}$ Dr. Robert Bell, “The Cobalt Mining District," Jour. Can. Mining Institute, 1907 , p. 64 . 
solutions. Chlorite, sericite and quartz are well known to be stable minerals, and it therefore follows that the arkoses cannot have been active agents in depositing the ores.

The graywacke is made up of similar minerals with a larger percentage of secondary products. Calcite is sometimes present in very small amounts, and it is noteworthy that these rocks show a marked deficiency in lime, as compared with the Keewatin. It is thought therefore that while the Keewatin greenstones have probably, by virtue of their mineralogical composition, played an important role in the deposition of the ores, the graywacke, being composed of more stable minerals and low in calcite, played the same role in a minor way, if at all. The pebbles in the conglomerate contain numerous primary ferro-magnesian minerals which would be readily decomposed, and so the coarse conglomerate may have been more active than the graywacke slate.

Owing to their regular vertical jointing these sediments have afforded the most suitable place for the deposition of the ore, and so it happens that many of the most valuable veins have been found in them.

\section{DEPTH OF COBALT-SILVER VEINS.}

Miller has pointed out that marked changes in silver values take place in passing from conglomerate to Keewatin rocks. Considerable silver is being mined from the latter; but it has in most cases been found that the veins are not so regular as in the overlying shell of conglomerate. The lower limit of the deposits has not yet been determined. There are no borings of more than a few hundred feet, and it is consequently not known whether there is another diabase sill at a lower horizon. Solutions from a lower sill would find in the intruded Keewatin an agent which assists in deposition; but there can be no repetition of the Huronian sediments.

\section{CONCLUSION.}

It has been shown that cobalt ores have been deposited from solutions which followed the formation of veins of aplite in the diabase. Owing to the fact that in all the silver deposits in the 
district the silver minerals are intimately associated with cobalt minerals, the silver is believed to have the same origin.

It is suggested that the metallic sulphides and arsenides have been concentrated from the diabase magma by extreme differentiation.

The Keewatin igneous rocks have assisted in the ore deposition on account of their content of calcite and unstable minerals.

The Huronian sediments are composed for the most part of stable minerals with little calcite, and their chief function has been that of a recipient for the ores.

If these conclusions are correct, we may expect to find similar ore deposits where the diabase sills are associated with Keewatin igneous rocks, and especially valuable deposits where Huronian sediments are also present. The region from Lake Temiscaming to Lake Huron doubtless includes many such occurrences. 